\title{
Lumen
}

Selected Proceedings from the Canadian Society for Eighteenth-Century Studies

\section{The Travels of Sethos}

\section{Jay Macpherson}

Volume 23, 2004

URI : https://id.erudit.org/iderudit/1012197ar

DOI : https://doi.org/10.7202/1012197ar

Aller au sommaire du numéro

Éditeur(s)

Canadian Society for Eighteenth-Century Studies / Société canadienne d'étude du dix-huitième siècle

ISSN

1209-3696 (imprimé)

1927-8284 (numérique)

Découvrir la revue

Citer cet article

Macpherson, J. (2004). The Travels of Sethos. Lumen, 23, 235-254.

https://doi.org/10.7202/1012197ar

Copyright (C Canadian Society for Eighteenth-Century Studies / Sociéte canadienne d'étude du dix-huitième siècle, 2004
Ce document est protégé par la loi sur le droit d'auteur. L'utilisation des services d'Érudit (y compris la reproduction) est assujettie à sa politique d'utilisation que vous pouvez consulter en ligne.

https://apropos.erudit.org/fr/usagers/politique-dutilisation/
Cet article est diffusé et préservé par Érudit.

Érudit est un consortium interuniversitaire sans but lucratif composé de l’Université de Montréal, l'Université Laval et l'Université du Québec à Montréal. Il a pour mission la promotion et la valorisation de la recherche. https://www.erudit.org/fr/ 


\section{The Travels of Sethos}

Most present-day readers who have heard of the Abbé Terrasson's novel Sethos, 1731, know of it as the source of the Egyptian setting of Mozart's opera of sixty years later, Die Zauberflöte (The Magic Flute), with text by Emanuel Schikaneder. Since that relationship, well covered elsewhere, ${ }^{1}$ has overshadowed other dimensions of Sethos' influence, this paper will treat The Magic Flute only peripherally, going on to at least sketch out the book's absorption into eighteenth-century scholarship, its use by Masonic authors, its rediscovery by literary authors, and its reach, it seems via the Freemasons, into the late twentieth century.

The Magic Flute's hero Tamino, charged in an unlocalized 'rocky landscape' with the rescue of the abducted Pamina, finds that his quest lies in the realm of her abductor Sarastro, which explicitly is Egyptian. Scene 9, where we hear more of Pamina, opens in 'a magnificent Egyptian room' with canals and palm-groves near by. The three temples of Scene 14 are of unspecified type; but Sarastro's priestly conclave $(2.1)^{2}$ assembles in a grove of palms fashioned in gold and silver with a miniature pyramid beside every seat (a setting altered or much simplified in modern productions), and Isis and Osiris are invoked as patrons of the mysteries practised here. The important scenes of the ordeals through which Tamino must pass involve ancient-Egyptian portals (2.2), 'the vault of the Pyramids' (2.20, shown in an engraving in the libretto), and a small pyramid bearing an inscription (2.28). At their moment of triumph Tamino and Pamina, in priestly garments, stand surrounded by

1 Peter Branscombe, W. A. Mozart, Die Zauberflöte (Cambridge: Cambridge University Press, 1991 - Cambridge Opera Handbooks), p. 10-18, discusses definite, probable, and possible Sethos connections. This is a searching and careful study with a useful bibliography. See also Alfons Rosenberg, Die Zauberflöte: Geschichte und Deutung von Mozarts Oper (Munich: Prestel, 1964), especially p. 172-73.

2 Emanuel Schikaneder, 'Die Zauberflöte, eine grosse Oper in zwey Aufzügen [a grand opera in two acts]' (Vienna: Alberti, 1791); facsimile edition by Michael M. Rabenlechner (Vienna, 1942; reprint, Bremen: Faksimile-Verlag, 1983). All subsequent references are to this edition and references are to act and scene. 
'Egyptian priests' (footnote 2). 'Egypt' evidently carries lofty meanings for this audience.

From classical times to the end of the eighteenth century, Egypt with its inscrutable monuments was widely seen as the home and heartland of ancient wisdom. Classical authors related how significant figures such as Orpheus, Daedalus, Homer, Solon, Thales, Pythagoras, Plato, came to Egypt to learn. The author of the Acts of the Apostles described Moses, in Bible story raised by Pharaoh's daughter, as 'learned in all the wisdom of the Egyptians' (chap. 7, v. 22). This account later became a pretext for pressing the text of Scripture - whose first five books legend attributes to Moses - for layered allegorical meanings: was not this learning ancient and mystical? and were not the hieroglyphs its specially designed vehicle? Till the early seventeenth century the Hermetic writings were believed to originate in Egypt, home of Hermes Trismegistus; as well, a false etymology of 'alchemy' made it the 'Egyptian' art. Fanciful views of Egyptian learning and religion predominated until the new era in Egyptian studies that was ushered in by Napoleon's Nile expedition of 1798 and its slow scholarly aftermath culminating in the deciphering of the hieroglyphs through the Rosetta Stone. Up to then European scholars had to depend mainly on the reports of the ancient Greeks, to whom the spoken language of contemporary Egyptians was no less a closed book than that of the inscriptions.

A major contribution to building up the image of Egypt before the eighteenth century was the prodigious but misguided work of the Jesuit polymath Athanasius Kircher, whose publications on the hieroglyphs run from 1636 to 1667 . They are heavily learned, lack at most points any insight into the actual language, and insist on a Neoplatonic or theosophical style of interpretation. Thus an inscription on the obelisk being re-erected in 1650 by Bernini on the Piazza Navona stating, as later became plain, that 'the august Caesar Domitian' had ordered this obelisk and had the inscription cut in Rome, was interpreted by Kircher, 'The four-powered beneficial guardian of celestial generation, dominator of air, through Mophta commits benign aerial humour to Ammon, most powerful of inferiors, so that by images and fitting ceremonies it is potently expressed. ${ }^{3}$ Kircher assumes, moreover, that all hieroglyphic inscriptions represent the pure early religion transmitted by Noah and written down under the instruction of Hermes Trismegistus shortly after

3 Don Cameron Allen, Mysteriously Meant: The Rediscovery of Pagan Symbolism and Allegorical Interpretation in the Renaissance (Baltimore: Johns Hopkins University Press, 1970), p. 127, quoting Obeliscus Pamphilius (1650). 
the Flood, before it degenerated and was replaced by polytheism, animal-worship, idolatry, and magic. This view of early religions as forms of a sublime monotheism was favoured by many Enlightenment writers, convinced that the chief secret imparted to initiates of the mystery-religions, the kernel hidden by the husk of stories and images of the gods often gross or less than human, was the oneness of the Divine.

The Magic Flute's Egyptian materials look back to a minor genre of didactic fiction - tales of the travels of young princes learning to become enlightened rulers, recalled when Sarastro encourages Tamino to continue through the trials if your heart still beats as warmly for Pamina, and if you want one day to rule as a wise prince' (2.21). These novels graft an up-to-date interest in the laws and customs of other nations onto the Renaissance concern with the education of the prince that reaches back to Xenophon's account of the career of Cyrus, pattern of the ideal ruler. The genre is mainly French, starting with Fénelon's Les Avantures de Télémaque (Paris: Barbin, 1699), a prose continuation of the Odyssey directed at his ex-pupil the young Dauphin. Télémaque is guided on his tour of the Mediterranean world by the sage advisor Mentor, revealed at the end of the journey to be the goddess Minerva in disguise. It was Fénelon's treatment rather than Homer's that brought the word 'mentor' into common speech, and the tutor or wise older man continued to feature. Télémaque remained popular over most of the next century Richardson's Pamela, not a very bookish maiden, read it in English and her friend Parson Williams in French - and one of the last of its many imitations and adaptations was Schikaneder's 'grand heroicomic opera' of 1795, Der Königssohn aus Ithaka. ${ }^{4}$ Alexander Pope as a boy began a verse imitation, and late in life commenced an epic on the Trojan prince Brutus, who before founding his empire in Britain 'is supposed to have travelled into Egypt, and there to have learned the unity of the Deity, and the other purer doctrines, afterwards kept up in the mysteries. ${ }^{15}$ The Chevalier Andrew Michael Ramsay, tutor to the sons of James II, an admirer of Fénelon and later important in Freemasonry, wrote a prose imitation of Télémaque called Les Voyages de / The Travels of Cyrus, published 1727 in Paris and London. Then comes the Abbé Jacques Pernetti's Le Repos de Cyrus (Paris, 1732), a favourite of Lessing; a not-so-distant relative is Samuel Johnson's Rasselas, Prince of Abyssinia (London, 1759).

4 The libretto (Brunswick, 1795) is available in the Library of Congress (M1503 H696 K5 [case]).

5 Joseph Spence, Anecdotes, ed. James M. Osborn (Oxford: Clarendon, 1966), 1: p. 153. 


\section{Jean Terrasson's Sethos}

Sethos, histoire ou vie tirée des monumens anecdotes de l'ancienne Égypte (Paris, 1731), was issued anonymously. ${ }^{6}$ Playfully purporting to be translated from a Greek manuscript of the time of Marcus Aurelius, it was shortly acknowledged as the work of the Abbé Jean Terrasson, an able mathematician and professor of Greek and Latin Philosophy at the Collège de France, who within a few years would publish a translation ('the execution is tolerable,' said Edward Gibbon ${ }^{7}$ ) of his main classical source, the universal history of Diodorus of Sicily. Like Fénelon, by the way, Terrasson bequeathed one small element to modern speech: in Sethos he altered Diodorus' version of the inscription over the entrance of a library at Thebes, 'Medicine for the Soul,' to 'Food for the Mind' (Lediard's translation of 'La Nourriture de l'Ame' [p. 70]), which Frederick the Great, who admired the book, had inscribed over that of the royal library in Berlin ('Nutrimentum Spiritus'). ${ }^{8}$ Less admiring was Gibbon, who observed in Sethos 'far more originality and variety' than in Télémaque, but added that it lacked Fénelon's charm of style and power to address the heart. ${ }^{9}$

Terrasson's Sethos, which earned him membership in the Académie française, is a high-minded romance, exotic and aristocratic, and well supplied with lengthy moral discourses. Its operatic family plot relates it distantly to the French heroic fictions of the seventeenth century, though with a much simpler action and a very restrained treatment of love. A minor player in the querelle of the Ancients and Moderns, Terrasson stated in his Dissertation Critique sur l'Iliade d'Homère (Paris: Fournier and Coustelier, 1715), that he aimed to 'faire passer jusqu'aux belles lettres cet esprit de Philosophie, qui depuis un siècle a fait faire tant de progrès aux Sciences naturelles' (préf. p. iii). Unmoved by the thoughtless adulation of more than two millennia, he found that the Iliad failed to conform with 'la droite raison et la belle nature' (p. iv). He noted

6 References here are to vol. 1 of the closely similar two-volume Amsterdam edition of 1732.

7 Edward Gibbon, English Essays, ed. Patricia B. Craddock (Oxford: Clarendon, 1972), p. 551.

8 John Colin Dunlop, History of Prose Fiction, ed. Henry Wilson (London: Bell, 1896), 2: p. 359.

9 'Critical Observations on the Design of the Sixth Book of the Aeneid,' in English Essays, p. 150. 
the human failings attributed by Homer to both gods and men, and especially his failure to 'corriger son siècle par les vûës les plus simples du sens commun \& de la morale naturelle' (p. xxxiv). His conclusion finds Homer inferior to such moderns as Racine and particularly Fénelon, later the declared model of his own didactic romance.

Terrasson's entirely fictional hero, a prince living a generation before the Trojan War, is born into an Egypt of high civilization, 'mere des Sciences et des Arts' (p. 13). Neglected by his indolent father and hostile stepmother but trained in body, mind and moral sense by his tutor Amedès, he is guided by him to seek initiation as part of his preparation to become an enlightened ruler. The Great Pyramid, vaingloriously built by Cheops at vast expense, has been sagely adapted by a wise priesthood to serve as the entry to, first the scene of the candidate's trials, and then a whole further underground realm where the priests conduct their lives and arrange instructive shows. Amedès guides Sethos to a window in the Pyramid's north face that gives entrance to a narrow pathway leading to a deep well with rungs in its wall; descending and following a lower path, Sethos reaches an arch on whose pediment is inscribed: 'Quiconque fera cette route seule, et sans regarder derriere lui, sera purifié par le feu, par l'eau, et par l'air; et s'il peut vaincre la frayeur de la mort, il sortira du sein de la terre, il reverra la lumiere, et il aura droit de préparer son ame à la revelation des mysteres de la grande Déesse Isis' (2.125). In the hands of Schikaneder, the Flute's librettist, this becomes the inscription that the two Armed Men (reduced from three in Sethos) read to Tamino from the side of a small pyramid at the entrance to the trials by fire and water ${ }^{10}$ :

That man who treads this road with all its many hardships

By fire and water, air and earth, is cleansèd;

If he beyond the haunting fear of death can rise,

From earth ascending, soaring to the skies,

Enlightened, he'll have reached a fitting state

To Isis' mysteries himself to consecrate.

10 Der, welcher wandert diese Strasse voll Beschwerden,

Wird rein durch Feuer, Wasser, Luft und Erden;

Wenn er des Todes Schrecken überwinden kann,

Schwingt er sich aus der Erde Himmel an.

Erleuchtet wird er dann imstande seyn,

Sich den Mysterien der Isis ganz zu weih'n. (2.28)

(Translations not otherwise attributed are my own.) 
Sethos then passes elaborate pre-initiatory trials representing the elements. First comes an ordeal by fire, though the vaulted room with flames only looks like a burning furnace and there is footroom between the glowing bars in the floor. Next a canal is to be swum; last he springs (or is precipitated?) from a drawbridge in unpredictable motion, grasps two rings, and hangs in the air amid noise and agitation before a two-leaved ivory door opens and admits the weary hero to the brilliantly-lit hall of the Temple of Memphis, where he is congratulated by the priests. (In The Magic Flute these trials are simplified: Tamino first passes through underground passages, then with Pamina he walks playing his flute through two small hollow mountains, one filled with fire and one with water; immediately 'the entrance to a brightly lit temple becomes visible,' [2.28] and when the couple enter the temple, 'the whole set changes into a sun.' [2.30]) Here after long instruction Sethos is initiated into the mysteries of Isis, realizing along the way that his tutor Amedès is himself an advanced initiate. After returning to court at the end of book 4, during much of the remaining six books he travels east, then south, assisting several mainly African nations against their oppressors and extending his knowledge of the world. When eventually he returns home, he refuses the throne and becomes a member of the Egyptian priestly college.

1732, the year following its publication, saw Sethos translated into English by Thomas Lediard, who had been living in Hamburg and running the Hamburg Opera, and into German (Abriss der wahren Helden-Tugend [Outline of True Heroic Virtue]) by C. G. Wendt, ${ }^{11}$ a minor writer who probably knew Lediard through the theatre; so one may well have suggested it to the other. 1734 saw an Italian translation, 1767 a new French edition (there were six altogether, to 1825); ten years later Sethos was translated again into German by the poet Matthias Claudius. There were also three dramatizations, all dealing with Sethos' later career and especially his famous renunciations - as Dunlop says in his History of Fiction, (2: p. 356), 'resigning his kingdom to one brother and his mistress to another.' First came a French closet-drama in capable couplets, Alexandre Tan[n]evot's Sethos, tragédie nouvelle

11 Christoph Gottlieb Wendt, Abriss der wahren Helden-Tugend, oder, Lebens-Geschichte des Sethos, Königes in Egypten: aus geheimen Urkunden des alten Egypten-Landes gezogen, und nach der frantzösischen Übersetzung eines griechischen Originals verteutschet [Outline of True Heroic Virtue, or Life-History of Sethos, King of Egypt, taken from Secret Records of Ancient Egypt, and translated into German from the French Translation of a Greek Original] (Hamburg, Wiering and Leipzig: Hertel, 1732). 
dediée au grand Corneille (Paris, 1739), then a school drama in Latin, Sethos Aegypti Rex, 1758, and finally a five-act heroic drama more remotely based on Sethos, Thamos König in Aegypten, $1773{ }^{12}$ for which in 1773 Mozart, then seventeen and in Vienna, set two choruses; in 1779-80 at Salzburg he composed also some orchestral pieces. Its author was Tobias Philipp von Gebler, a member of the Viennese State Council, a conscious Enlightener whose plays, as a notice of his death remarked, were written 'in order to bring good taste to the stage. ${ }^{13}$ Sethos here is the assumed name of the deposed monarch Menes living unknown as highpriest of the Temple of the Sun in Heliopolis; his renunciation is in favour of his daughter and her bridegroom Thamos, son of the usurper but also Sethos' worthy pupil. Thamos carries a noble morality, showing a ruler's self-denying care for his people; but though it was translated into French and Italian, its success was short-lived. Thamos' name lives on in Schikaneder's Tamino.

The most striking of the three is the Salzburg Benedictine University and Gymnasium drama Sethos Aegypti Rex, by virtue of its imposing baroque structure. ${ }^{14}$ It interweaves two stories - that of Sethos as a five-act play, and a roughly similar story from the Old Testament, that of David, Solomon, and the pretender Adonijah, as a four-part opera or oratorio; it had also two 'Zwischenspiele' or comic interludes, evidently in German. A comparable work - same place, same composer (Johann Ernst Eberlin, a Salzburg acquaintance) - gave Mozart, aged five, his stage debut three years later.

Terrasson's main source for his account of Egypt is the Greek historian Diodorus of Sicily (1st century B.C.E.), whose Book 1 is devoted to Egypt as by tradition the earliest homeland of the gods, of astronomy, and of many heroes..$^{15}$ His account of the Egyptians is on the whole admiring: he dwells on what he finds rational and practical in their institutions and rationalizes much of the rest. For him the gods of Egypt are simply its early rulers, deified after their deaths; the wisdom of the priests concerns ritual, historical record-

12 Theatralische Werke, vol. 3 (Prague and Dresden, 1772-73).

13 Bayreuther Zeitungen, report dated 16. x. 1786, appended to no. 124.

14 An elaborate program survives in the Österreichische Nationalbibliothek in Vienna (1833-B. Mus).

15 [Library of History] vol. 1, trans. Charles H. Oldfather (London: Heinemann, $1933-$ Loeb Classical Library), bk. 1, chap. 9, sect. 6. All further references are to bk. 1 in this edition and references are to chapter and section. 
keeping, and practical abilities like applying what you learn from the stars to the seasonal needs of agriculture. Isis and Osiris correspond to the Greek Demeter and Dionysus; Erechtheus, an early king of Athens, brought her rites to Eleusis, and Orpheus brought his to Thebes $(29.2 ; 23.2)$. (In fact the mysteries of Isis began in the Greco-Roman world and appear to have been shaped by those at Eleusis, while the Egyptian 'mysteries' of Osiris, pertaining directly to kingship and succession, are quite unrelated to those of Dionysus.)

Diodorus' determination to find in history notable examples of vice and virtue and to rationalize the non-rational appealed to Terrasson's own temper. In his opening chapter Diodorus announces the moral uses of history: it commemorates worthy deeds, and is even more powerful than the myths of Hades in fostering piety and justice. Terrasson considered fiction still more effective than history as an instrument of moral teaching, and thought belief in posthumous reward and punishment was useful for inculcating virtue in those who had no worthier incentive. He indicates in Sethos that the mythology of Hades was all derived, along with stories about underworld journeys like those of Orpheus and Aeneas, from one of two Egyptian institutions: particularly their initiations and the shows and mimes associated with them, but also their funerals, involving a trial of the deceased by a panel of human judges before his body could be rowed across the lake called Charon and admitted to the 'labyrinth' beyond for burial — so Diodorus understands the judgment of the dead that in Egyptian belief actually was conducted in the underworld by divine judges before the soul could be admitted to the afterlife.

\section{The Initiation Theme: Warburton}

Diodorus gives no information at all about the content of Isis' rites; Terrasson's account of Sethos' ordeals before his instruction and initiation is based on Apuleius' Golden Ass. He greatly expands a phrase from the famous passage in which Lucius describes the climax of his initiation into the mysteries of Isis: 'I approached the borders of death, and after treading the threshold of Proserpina, and having been borne through all the elements, I returned; in the middle of the night I saw the sun shining with brilliant light' (bk. 11, sec. 23). Again, Aeneas in Virgil's underworld hears of a purgatorial process involving winds, a watery gulf, and fire, and like Sethos will leave by an ivory door (bk. $6,11.740-2,895-8)$. 
The title of the Comte de Caylus' very lightweight story of about $1742,{ }^{16}$ 'Les épreuves d'amour dans les quatres éléments,' in which Alexis rescues his Eulalie successively from burning, drowning, hanging, and burial alive, suggests that the notion of testing by the elements was already familiar to Caylus' educated readers. Some Freemasons in particular seized on it. The first-degree or Apprentice initiation-ritual practised in some Viennese Masonic lodges in the 1780s, including Mozart's own lodge Wohltätigkeit (Benevolence), used a light splash of water and the burning of rosin to symbolize trials by water and fire ${ }^{17}$ - an addition to the English ritual from which it was derived. In a toast to the traveller, scientist and Freemason Georg Forster at a dinner given by Wohltätigkeit's sister lodge Zur wahren Eintracht [True Concord] on August 15, 1784 (four months before Mozart became a Mason), the poet Aloys Blumauer compared Forster's experience with the symbolic travels and ordeals of the new Mason's reception: 'The noble fellow here in our circle, / Who, while we accomplished so many Masonic journeys / Comfortably on a smooth floor, / Circumnavigated the globe, / And there, borne through all the elements, / Could tell us more of heaven's dew and lightning / Than many an apprentice, suffering however much / From fire and water... . ${ }^{18}$ The clause from Apuleius in conjunction with the Masonic trials suggests that the 'trials' were added to the ritual to give deeper historical resonance, Terrasson's influence very likely playing a part.

For Terrasson there is nothing mystical or other-worldly about what Sethos achieves by his initiation, which is a process of testing, strengthening and guiding those who are to be rulers and statesmen, and developing their self-knowledge and self-control. As part of the instruction that precedes his initiation, Sethos is given a guided tour of a region modelled on Virgil's account of the underworld in the Aeneid book 6,

16 Anne-Claude-Philippe de Tubières, Comte de Caylus, Les Étrennes de la Saint-Jean (Paris [1742?]).

17 Hans-Josef Irmen, Mozart's Masonry and the Magic Flute ([Zülpich]: Prisca, 1996), p. 92.

18 Dem Edlen hier, in unserm Kreise,

Der, während wir so manche Maurerreise

Auf eb'nem Boden ganz bequem vollbracht,

Die Runde um die Welt gemacht:

Der da, geführt durch alle Elemente,

Vom Thau des Himmels und vom Blitze mehr

Als manche Lehrling, der auch noch so sehr

Von Feuer und Wasser litt, uns sagen könnte....

(Georg Forsters Werke (Berlin: Akademie Verlag, 1958), 14: p. 166-67, letter of 14-16 August 1784 to S. T. Sömmering.) 
where he sees mainly a series of theatrical shows of reward and punishment. Among his several citations of modern scholars, Terrasson (p. 144) quotes Lafitau's statement, expanding in turn on Cicero, that initiation into the mysteries was a practical school of religion and virtue, instituted by the ancients to instruct men how to live by the principles of reason and prudence. ${ }^{19}$ Sethos is the first work of fiction since the Renaissance to give the subject of initiation any space; and by the length and seriousness of its treatment it gets both that subject and the recharged image of Egypt as the homeland of mysterious wisdom launched for the next several generations.

Sethos' adventures, though offered only playfully as fact and indeed prefaced with an essay on the moral uses of fiction, were taken up for a while by the serious scholarship of the age, with its desire to understand the nature and therefore the early history of religions - first and most influentially by William Warburton, defender of Anglican orthodoxy and later Bishop of Gloucester, the author of The Divine Legation of Moses (London: 1738-41). Contemporaries thought him a marvel of erudition because, trained as an attorney and with no other education beyond grammar-school, he had made himself into a considerable scholar, his Divine Legation being a kind of Golden Bough of its age. Its argument based on theological paradox convinced few, but two parts became famous. His essay on the Egyptian hieroglyphs (book 4) made a lasting contribution, showing these as an early stage in the natural progression from pictures to letters, designed for convenience rather than secrecy, and thus not after all the designated vehicles of mystical content. This was well received especially on the continent: the essay's publishing history in French translation extends from 1744 via the Encyclopédie, which copies it, to 1977.

Also famous was his exposition of the sixth book of the Aeneid, Aeneas' journey through the underworld, as a symbolic account of the initiation of the Emperor Augustus into the Eleusinian Mysteries (book 2). Warburton assumes that the Mysteries, invented in Egypt and thence carried to Greece, were a deliberate contrivance (not of priests but) of rulers or 'Legislators' to convey to chosen individuals the useful doctrine of an afterlife:

Virgil, in this poem, was to represent a perfect Lawgiver, in the person of Aeneas; but Initiation into the Mysteries was what sanctified his Character and Function.

19 Sethos, p. 144; Père Joseph-François Lafitau, Mœurs des sauvages amériquains comparées aux mœurs des premiers temps (Paris, 1724), 1: p. 203; Cicero, De legibus, bk. 2, chap. 14, sec. 36 . 
For it was no Wonder the Legislator should endeavour by his own Example, to ennoble an institution that was of his own creating: Accordingly, we find all the ancient Heroes and Legislators were in Fact initiated. ${ }^{20}$

Warburton's vigorous and detailed exposition of Aeneas' journey leans very heavily indeed on the account in Sethos, though his extensive notes fail altogether to mention it. His debt was quickly noted by a couple of minor writers, and spelled out later by Gibbon in an essay on the defects of Warburton's classical scholarship, much of it in a tone that Gibbon later regretted: 'This notion [of seeking the poets' image of Hell in the Egyptian Mysteries] was published in French, six years before it was invented in English. ${ }^{21}$ But Warburton's account, in his clear, emphatic prose, was published separately as a monograph, and reprinted for inclusion in commentaries on Virgil from Joseph Warton's Virgil edition of 1753 to P. W. Buckham's Miscellanea Virgiliana, 1825, yet farther diffusing features of Terrasson's romance, still unacknowledged. When Voltaire, in the Essai sur les mœurs (1741), mentions 'le sixième livre de l'Énéide qui n'est que la description des mystères d'Isis et de Cérès Éleusine,' he has it from Warburton; however, realizing that nothing in Aeneid 6 related to the Eleusinian myth, he later corrected this account. ${ }^{22}$

\section{The Initiation Theme: the Freemasons}

What made the 1730 s and 40 s particularly propitious for pseudohistorical accounts of initiation was the growing interest of Freemasons in initiatory cults and traditions and of everybody else in Freemasonry. The medieval brotherhoods of working stonemasons developed rituals to admit qualified members to their craft and signs by which travelling members could make themselves known. Reaching its modern form in London in 1717 as a middle-class club with no special trade affiliation, Freemasonry then spread vigorously, taking on a variety of social and political colourings and legendary provenances. While the central myth of British Freemasonry concerned the building of Solomon's temple, The Constitutions of the Free-Masons (London, 1723), by James Anderson, a pretentious writer bent on puffing up the prestige of his subject, offers numerous hints about other Eastern sources for its

20 Divine Legation, 3rd ed. (London, 1742-58), 2: p. 199-200.

21 'Critical Observations,' p. 150.

22 CEuvres complètes (Paris: Garnier, 1877-83), 11: p. 66, 'Les Monuments des Égyptiens'; 19 (vol. 3 of Dictionnaire philosophique as defined in that edition): p. 467-68, 'Initiation.' 
traditions - Chaldeans and Mages, the learned Jews of Babylon, and Pythagoras the pupil of the Egyptians. A pamphlet of 1730 reissued in the Constitutions edition of 1738 links the Freemasons with the Pythagoreans, the Essenes, the Cabala, the Druids, and 'the old Egyptians. $^{23}$

Terrasson, unlike one or two of his translators, ${ }^{24}$ does not appear to have been a Freemason: few in France had joined by 1731. But when in later decades the Freemasons and their sects and rivals launched into print either to claim high antiquity for their own traditions or to expose the claims of others, Sethos' adventures underground provided useful material.

A book published in 1770 directly connects Freemasonry with Africa. Its author is Karl Friedrich von Köppen, military adviser in the service of Frederick the Great of Prussia, and Grand Master of a somewhat mystical Berlin lodge called the African Master-Builders. He has evidently picked up a hint from Anderson: 'We may readily believe, that the African Nations, even to the Atlantick Shore, did soon imitate Egypt in [architecture], though History fails, and there are no Travellers encourag'd to discover the valuable Remains in Masonry of those once Renowned Nations' (p. 24). Köppen's book has the inscrutable though Greek-sounding title Crata Repoa, and is subtitled Einweihungen in der alten geheimen Gesellschaft der Egyptischen Priester [Initiations into the Ancient Secret Society of the Egyptian Priests]. Published anonymously, and ingeniously put together out of every available scrap of ancient text bearing on initiations, it purports to outline the rituals by which candidates were received into a series of seven degrees. These have the usual Masonic machinery of guarded doors, knocking for admission, blindfolds, warnings, cabinets of reflection, skeletons, weapons, costumes, oaths, and so forth, but most of the details are linked to classical references (Diodorus, Apuleius, Iamblichus, etc.), evidently without contamination by Sethos.

23 A Defence of Masonry, ascribed to Martin Clare, was a response to the first major exposure of Masonic ritual, Samuel Prichard's Masonry Dissected, 1730. Prichard 'lay[s] the Original Scene of Masonry in the East, a Country always famous for Symbolical Learning, supported by Secrecy; I could not avoid immediately thinking of the old Egyptians, who conceal'd the chief Mysteries of their Religion under Signs and Symbols, called Hieroglyphics...' (Defence, p. 219).

24 The Thomas Lediard who appears in London Grand Lodge minutes from 1743 to 1752 was not the translater (d. 1743) but his son (d. 1759). Matthias Claudius became a Freemason in 1773; his translation was published 1777-78. T. P. Gebler, the author of Thamos, 1773, had evidently joined well before that date (see Elisabeth Grossegger, Freimaurerei und Theater 1770-1800 [Vienna: Böhlaus, 1981], p. 24). 
Crata Repoa aims to provide the basis for an 'Egyptian' seven-degree rite (with Noah's son Ham as legendary founder) on an at least arguable scholarly foundation. By contrast Cagliostro's Maçonnerie Égyptienne of 1786 with its rituals for three degrees is largely costume and décor, with almost nothing classical or Egyptian but figures of Mercury and Minerva, a caduceus, and a pyramid; however, a purported Confessions $d u$ Comte de C... of 1787 repairs the omission with a tale, enhanced with a fanciful engraving of a stone bearing hieroglyphic directions for underground travel, of the Count's adventures in the Great Pyramid. ${ }^{25}$

Court de Gébelin in his Le Monde primitif, 1773-82, ${ }^{26}$ gives a version of Warburton's account of Aeneas' initiation, to be picked up by Abbé Claude Robin, a man of learning and incidentally a member of the famous Paris lodge Les Neuf Sœurs, in his Recherches sur les initiations anciennes et modernes (Dresden, 1781). Robin uses the narrative to support his argument of Freemasonry's descent via the orders of knighthood from the ancient mystery-religions (without the usual reference to the Crusades). On p. 14-16 details from Sethos - 'le jeu bruyant des machines l'enlevoit, le précipitoit, lui peignoit le sifflement des vents...les épreuves de l'eau, du feu \& de l'air' - are juxtaposed with a respectful but non-committal note on the book, which he claims to have seen only after completing his research. (Louis Guillemain de Saint-Victor, on the other hand, seeking in 1785 to ground his own brand of Masonry in ancient ceremonial, quotes and paraphrases Sethos directly over some thirty pages, with a brief footnote acknowledgement [p. 27]). ${ }^{27}$ Robin's view was carried to an extreme by Alexandre Lenoir, a respected archaeologist and curator of the Musée Royal des Monuments Français, in his La Franche-Maçonnerie rendue à sa véritable origine (Paris, 1814), defending 'l'opinion où je suis de ne voir dans la Franche-Maçonnerie qu'une imitation des mystères d'Isis, de Cérès, de Bacchus et d'Atys' (p. 6). Later he quotes a caution against mere curiosity addressed by the Master to the candidate for the first degree, claiming it is 'une imitation exacte de l'inscription qui se présentoit aux yeux de l'initié aux mystères d'Isis' (p. 240-41): the inscription Sethos reads at the entrance to his trials

25 L'Initiation, vols. 70-83 (Paris, March 1906 to June 1909); Les Confessions du Comte de C..., avec l'histoire de ses voyages en Russie, Turquie, Italie et dans les pyramides (Au Caire et à Paris: Cailleau, 1787).

26 Antoine Court de Gébelin, Le Monde primitif, vol. 4 of Histoire civile, religieuse et allegorique du calendrier ou almanach (Paris, 1776), p. 334-39.

27 Recueil précieux de la maçonnerie Adonhiramite (Paris, 1785; 1789 ed.), p. 134-66, p. 143n. 
follows. Lenoir's handsome quarto includes several large engravings from drawings made by Jean-Michel Moreau (the younger) about 1790 for a history of religions never published. One shows Sethos' ordeals: having escaped the fire he swims the canal, his clothes tied on his head; he then leaps from the drawbridge to grasp the rings over the ivory door. A second shows much the same setting, but here the priests in a later episode (book 4) are putting a penitent through a purifying ritual: with wrists and ankles bound he is dipped in a fire-resistant substance, pulled first over the iron grill and then through the canal, and given a few turns on one of the wheels that in book 3 controlled the drawbridge (hence, says Terrasson, the tale of Ixion's punishment). ${ }^{28}$

\section{Literary Adaptations}

In Germany at a more popular level speculation about 'Egyptian mysteries' gave rise to two kinds of fiction about Egypt - the idealizing, like The Magic Flute and other works drawing on Sethos, and more often the debunking, like a story by Christoph Martin Wieland, 'Der Stein der Weisen' [The Philosophers' Stone], whose charlatan magus describes an initiatory adventure in the depths of 'the great pyramid at Memphis,' where his tests of courage closely imitate Sethos' ordeals by water and fire $^{29}$. The story, which belongs to Wieland's explicit program of working against the current thirst for wonders, became the basis of Schikaneder's first 'magic opera' Der Stein der Weisen, 1790.

The Egyptian and initiatic interests that meet here and in The Magic Flute belong to a large context in popular - and some highbrow literature. The rise of Freemasonry followed by that of rival organizations, especially the Rosicrucian brotherhood and the Illuminati, provoked a general interest in secretive initiatic bodies - particularly in Germany, where it was expressed in novels and plays. This subject

28 The first engraving is reproduced in Mary Lefkowitz, Not Out of Africa (see n. 37 below), p.123, and in James Stevens Curl, the second (Moreau's drawing) in Jean-Marcel Humbert et al.'s, Egyptomania (Ottawa: National Gallery of Canada, 1994), p. 146.

29 From vol. 1 of Dschinnistan, oder Auserlesene Feen- und Geister-Mährchen [Genie-Land, or Selected Fairy-Tales and Ghost-Stories] (Winterthur, 1786-89), Wieland's collection of quasi-Oriental fairy-tales. The recently-discovered score of Schikaneders heroisch-komische Oper Der Stein der Weisen, ed. David J. Buch, was published by Hainholz, Göttingen, in 2002; recording, Telarc 80508 (Pearlman, Boston Baroque). The opening situation of 'The Magic Flute' is derived from another Dschinnistan tale, 'Lulu, oder Die Zauberflöte' in vol. 3, by Wieland's son-in-law A. J. Liebeskind. 
matter along with (sometimes combined with) that of the age of knighthood characterizes the German equivalent of Britain's Gothic fiction. Well-known examples are the role of the Secret Tribunal in Goethe's Götz von Berlichingen, 1773, and of the Society of the Tower in Wilhelm Meister's Apprenticeship, 1795-96. Following the trend, Schikaneder (already the author of Hanns Dollinger oder Das heimliche Blutgericht [or The Secret Tribunal], 1788), staged in June 1791, three months before The Magic Flute, a blank-verse drama about the Templars whose climax was an initiation scene. ${ }^{30}$

If The Magic Flute represents to any extent either Schikaneder's (very brief) or Mozart's (longer and more serious) Masonic experience, the second of its two acts is perhaps a heightened representation of the way an order dedicated to human enlightenment might conduct itself in a rather ideal world. A member of a Viennese lodge that closed about two years before the time of writing, again 1791, produced a literary parallel, once more dependent on Sethos. The poet is Johann Baptist Alxinger, whom Mozart, who in a letter of Sept. 12, 1781 had called him 'an excellent poet' for his translation of Gluck's 'Iphigénie en Tauride,' would certainly come to know from his frequent attendance at Alxinger's lodge, True Concord; but influence of either work on the other seems unlikely. In Alxinger's poem Bliomberis, a romantic epic inspired by Wieland's Oberon, a wise old man directs the knight to a Holy Brotherhood dwelling in Mauretania, where inside a steep cliff he sees a triangular white stone with an inscription about the ordeals ahead, then is tested by fire, water and air before entering a temple bright as midday. Alxinger has recast Sethos' pyramid trials in chivalric mode, though still with a North African locale. While naturally we read such passages in the light of Alxinger's history as Freemason and Illuminatus (and his courageous effort the next year to defend Viennese Freemasonry in his book Anti-Hoffmann), the material was very current: it would not have taken a Freemason to write this version. ${ }^{31}$

30 Schikaneder published Hanns Dollinger in his Sämmtliche theatralische Werke, vol. 1 (Vienna and Leipzig, 1792). The Templar drama is Johann von Kalchberg, Die Tempelherren: of particular interest to Freemasons, however, because of attempts from A. M. Ramsay in 1736 through to J. A Starck in the next generation to suggest that Crusaders or, particularly, Templars carried knowledge of such rituals home from the East.

31 Johann Baptist von Alxinger, Bliomberis: Ein Rittergedicht in zwölf Gesängen (Frankfurt and Leipzig, 1791), canto 10. 
Sethos' trials appear again in two highly serious fictions of the 1790s: Heinrich Jung-Stilling's Das Heimweh [Homesickness], 1794-96, and Carl von Eckartshausen's Kostis Reise von Morgen gegen Mittag: eine Reisebeschreibung aus den Zeiten der Mysterien [Kosti's Journey from Morning to Noon: A Travel Description from the Times of the Mysteries] (Leipzig, 1795): both are symbolic narratives of spiritual journeys somewhat akin to Pilgrim's Progress. Comparatively weightless but much more read were Étienne-François Lantier's Les Voyages d'Antenor en Grèce et en Asie, 1798 (' 1 'Anacharsis des boudoirs,' says Larousse), and Thomas Moore's The Epicurean, so late as 1827. Both, Lantier at considerable length, pick up the ordeals under the pyramids, with what Moore's reviewer Peacock calls the perils of 'combustion,' 'submersion,' and 'suspension. ${ }^{32}$ After some forty pages of approximate transcription from Sethos, Lantier with signal ingratitude brings on an evil priest named Séthon. The striking frontispiece (from a drawing by Charles-Abraham Chasselat) to the novel in CEuvres complètes (Paris: Bertrand, 1826), vol. 2, shows the aspirant entering on the ordeal of fire, watched by Terrasson's three armed men in animal-crested helmets (fig. 1). ${ }^{33}$ Moore's hero, pursuing a maiden glimpsed first at a festival at Memphis, finds the window that leads into the Great Pyramid, then the road of trials, where a blue flame writes over the vast portal a verse all too jauntily commencing,

You, who would try

The terrible track,

To live, or to die,

But ne'er to look back -

You, who aspire

To be purified there,

By the terrors of Fire,

Of Water, and Air, -

Enough. Then after a period of instruction in the underground region, he waits alone through the night for the final revelation; but what

32 'The Epicurean,' in Works (London: Constable, 1926), vol. 9, Critical and Other Essays, p. 27, where Peacock notes Sethos as a source for both this novel and The Magic Flute.

33 When on the way to his ordeals Sethos encounters 'trois hommes armez d'un casque qui étoit chargé d'une tête d'Anubis,' Terrasson characteristically notes, 'C'est ce qui donne lieu à Orphée [thought of as a main originator of Greek myths from Egyptian sources] de faire de ces trois hommes les trois têtes du chien Cerbère, qui permettoit l'entrée de l'Enfer sans en permettre la sortie' (p. 127-28). 
appears instead is the lady he has been following, and he escapes with her to the daylight. A fancy edition of 1839 has engravings based on drawings by Turner ${ }^{34}$ : figure 2 , with a hand of providence and still more swarming apparitions than Chasselat's, depicts the leap from the drawbridge. In Lantier and Moore, Terrasson's earnest reconstruction with its high moral purpose has petered out into, respectively, padding and atmospheric background, this last with Chateaubriand behind it and Poe ahead.

\section{Aftermath}

The progress of scientific Egyptology in the early nineteenth century did much to dispel false notions about Egypt. But publication of Egyptian monuments, especially in Denon's Voyage dans la basse et la haute Égypte (Paris, 1802; two folio volumes with 141 plates), gave rise to a fad for 'Egyptian' décor that, affecting among other things some cemeteries, many lodges, and some rituals, also furnished some of the strange dyes that coloured late-nineteenth-century occultism. This in turn, developing from Theosophy and its later sects and schisms, produced a hodgepodge literature of items like Clymer, The Mystery of Osiris or Ancient Egyptian Initiation, 1909, and Hall, Freemasonry of the Ancient Egyptians, 1937. ${ }^{35}$ Meanwhile the old Sethos material lingered in the less critical Masonic handbooks; for example, Albert G. Mackey repeats it under 'Egyptian Mysteries' in A Lexicon of Freemasonry, 1861, though his History of Freemasonry, completed by 1881, calls it 'a fictitious system indebted for its birth to the inventive genius of a French abbé. ${ }^{36}$ The 1880s saw also the completion of Robert Freke Gould's History of Freemasonry (London: Jack, 1882-87) and the founding in London of Quatuor Coronati, the first lodge dedicated to Masonic research: two major steps

34 The Epicurean, A Tale, with vignette illustrations by J. M. W. Turner, Esq. R. A., and Alciphron, A Poem (London: Macrone, 1839). The lyric quoted above is on p. 53.

35 Reuben Swinburne Clymer, The Mystery of Osiris or Ancient Egyptian Initiation (Allentown: Philosophical, 1909; rev. ed., 1951); Manly Palmer Hall, Freemasonry of the Ancient Egyptians (Los Angeles: Philosophers, 1937).

36 A Lexicon of Freemasonry, Containing a Definition of all its Communicable Terms, Notices of its History, Traditions, and Antiquities, and an Account of all the Rites and Mysteries of the Ancient World (London: Griffin, Bohn and Co., 1861), p. 82-85; The History of Freemasonry: Its Legends and Traditions, Its Chronological History (New York: Masonic History, 1898-1906), 1: p. 190. 
towards making Masonic history respectable. The classical scholar Mary Lefkowitz, in Not Out of Africa, 1996 - her response to Martin Bernal's Black Athena, 1987, and its relatives ${ }^{37}$ - gives Freemasonry in general responsibility for perpetuating down to recent times Diodorus' very unhistorical account, as packaged by Sethos, of how Greece acquired its religion, its heroes, its science and philosophy from the older civilization. After her trenchant spelling-out it would be hard to revive the older concept.

Jean Terrasson, that eager Enlightenment teacher, doubtless trusted that his harangues on false heroism and true virtue in rulers would be what a wise posterity would choose to keep alive: lessons indeed that the present age could use. It is just such features that he missed in Homer, 'qui fait toujours conter ses Héros au lieu de les faire raisonner' — and 'Une des marques de la médiocrité d'Esprit (dit la Bruyère) est de toujours conter; ${ }^{\prime 38}$ no more than his heroes does Homer himself reason or moralize. For a work that dropped from sight nearly two centuries ago, Sethos has had a notable influence; still, what has proved most durable is the most imaginative and colourful part of its 'conte,' still going strong in The Magic Flute. And, we might say, inspiring fresh fantasies in some critics; but that is a further story. ${ }^{39}$

\section{JAY MACPHERSON \\ Victoria College}

37 Not Out of Africa: How Afrocentrism became an Excuse to Teach Myth as History (New York: Basic, 1996); Black Athena: The Afroasiatic Roots of Classical Civilization (New Brunswick, New Jersey: Rutgers University Press, 1987).

38 La Philosophie applicable à tous les objets de l'esprit et de la raison (Paris, 1754), p. 156.

39 It might begin with Jacques Chailley, whose La Flute enchantée, opéra maçonnique (Paris: Laffont, 1968) persuaded a whole generation that the work was crammed with Masonic / esoteric symbolism. Briefly: convinced that 'toutes ces "sources"... restent très secondaires,' because '[l]a source essentielle ..., c'est avant tout le rituel maçonnique' (43) for which his own sources seem late, under-identified, and essentially French and with a preference for secondary reports over texts, he was content to know little more of either Dschinnistan or Sethos than he found in Edward J. Dent's Mozart's Operas (London, 1913). Witness, besides his liberal quotations from Dent, his assumptions that Wieland's Oberon, a significant book-length poem of 1780, is a Dschinnistan story (35) and that the Armed Men originate with the Flute libretto (125-6). His 1968 claim that Sethos is 'le plus maçonnique des modèles de l'ouvrage' (34) became 'le plus symbolique' (35) in the revised edition of 1983: still inappropriate, in view of Terrasson's determined rationalism. 


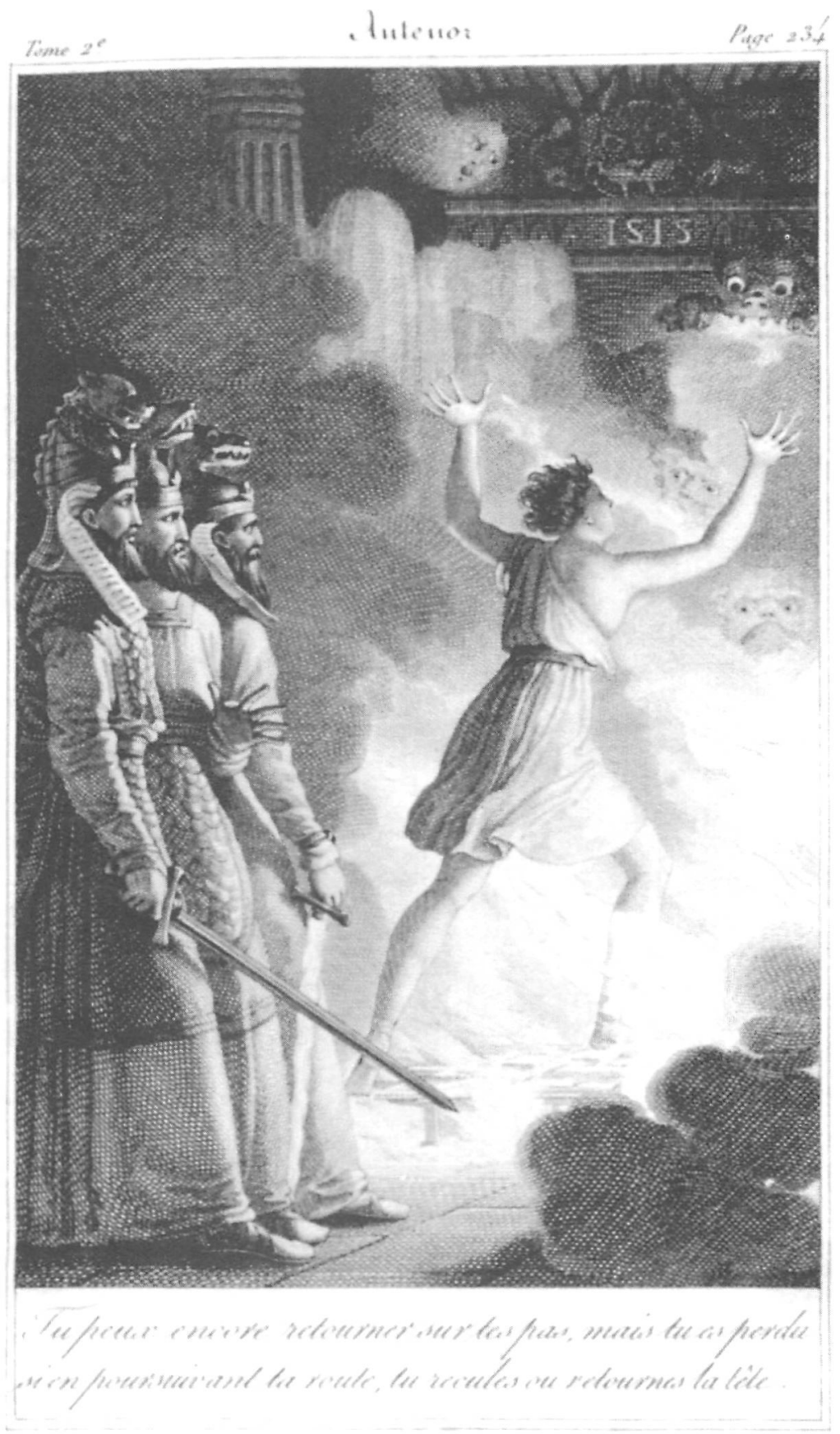

Figure 1. Entrance to the ordeals (Lantier).

Source: Robarts Library, University of Toronto. 


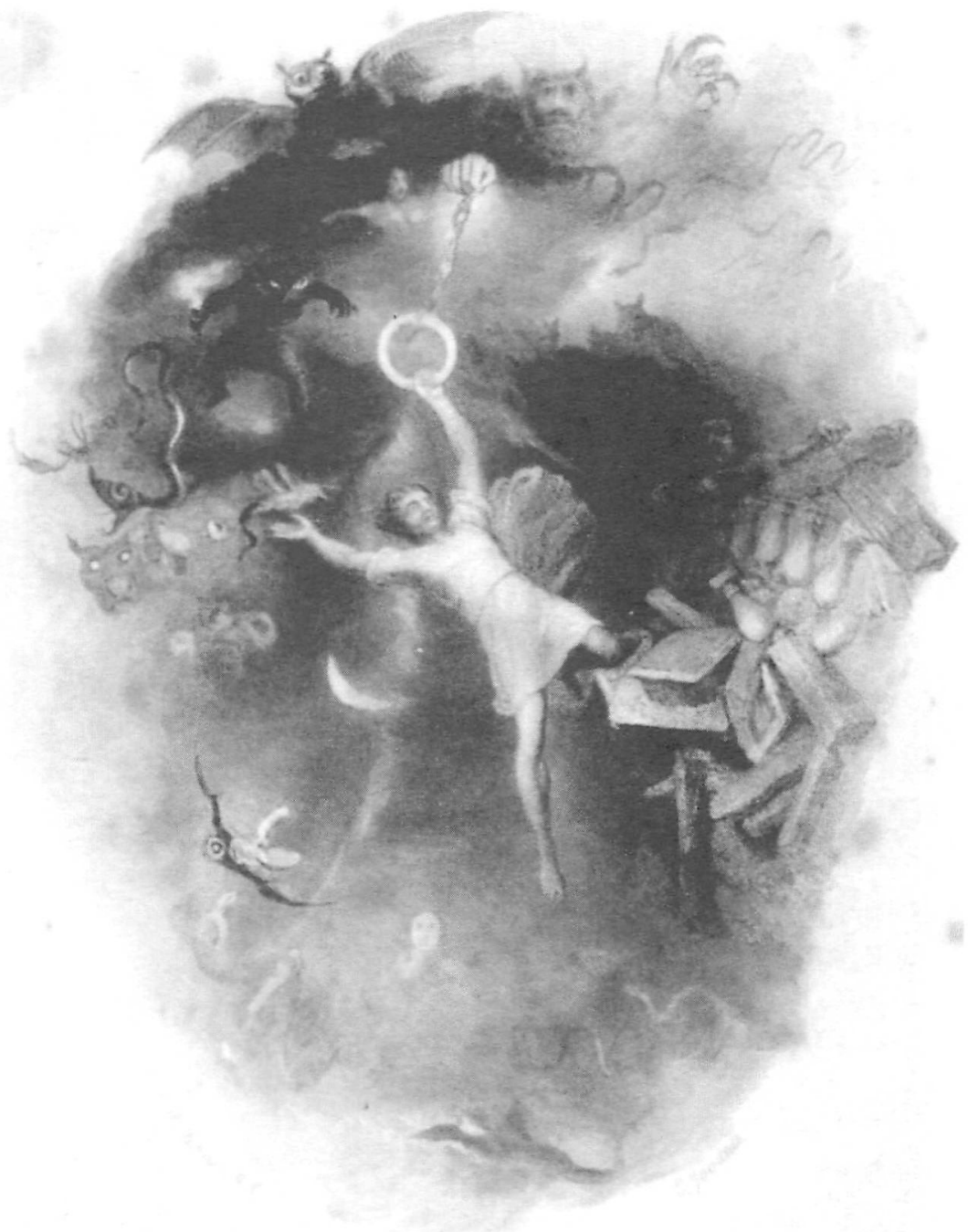

Figure 2. The ordeal by air (Moore). Source: Robarts Library, University of Toronto. 